\title{
Journey to Europe: Memory and the Path to TOMORROW
}

\author{
Noura KamaL, Vienna
}

\section{Content}

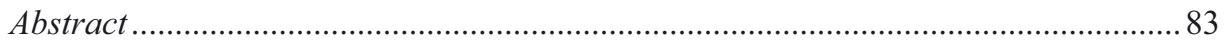

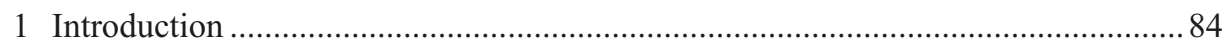

2 Remembering the past and the representation issue................................................... 85

3 The narrative of three men: The passage of seeking refuge ................................... 86

4 Analytical overview of the three narratives ....................................................... 93

5 The narration of three women: individual's agency within the suffering zone ........ 94

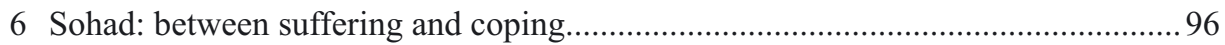

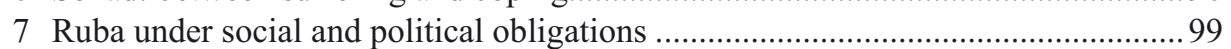

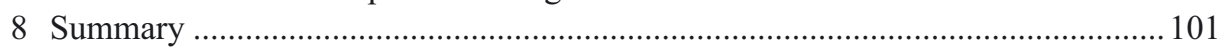

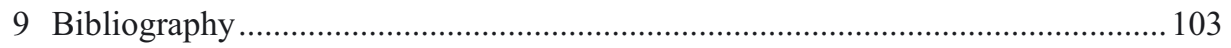

\section{Abstract}

Each individual has their own way of narrating the past, which reflects the different reasons for deciding to leave home and becoming a refugee. This became apparent after reading interviews of people from Syria who have come to Austria. Each story started from a different angle, whether by describing the political situation or by emphasising the social and economic aspects, which reveal the power relations that the individuals telling the stories are situated within. The memories they share with others and how they cope in their new place of living can tell us how women and men have different paths according to the circumstances that they find themselves in. From this point of view this paper will focus on gender relations, examining how migrants' narratives reflect their 
experience from different perspectives and how gender plays a vital role in their ability to be part of a new society.

Keywords: Memory, Gender, Adaptation, refugees

\section{Introduction}

In recent years, hundreds of thousands of refugees have arrived at Europe's borders escaping war and daily suffering due to political and social reasons. The emergence of political and religious extremism, preventing citizens from living a normal life and violating their human rights, has also caused the displacement of millions of people. During a large wave of migration during the summer of 2015, Austria was among the countries who welcomed the refugees, giving shelter, food, clothes, legal advice, and whatever they could provide.

Two of the main train stations in Vienna served as focus points: Westbahnhof and Hauptbahnhof. In each station, people from different backgrounds from Austria volunteered to help the refugees, many of whom came from places suffering from the ravages of war and conflict such as Syria, Iraq and Afghanistan. The volunteers quickly became very organised at the two stations, and at Westbahnhof, a professional organisation took over. Doctors were also present at both locations, helping as much as they could.

The first time I went to Westbahnhof station, it was a scene where social, ethnic and religious differences could not be seen and all the boundaries between people were dissolved. People from different parts of the world, belonging to different ethnicities, religions, nationalities, and different affiliations, were communicating with each other under the bond of humanity.

Each person who fled their home country has their different story depending on different variables (gender, religion, education, economic situation, political affiliation, etc.). Mentioning or describing how the refugees were able to cross over the boarders to reach a specific place can hardly show the real experiences they had. Based on what Arthur Kleinman says, refugees suffer twice; first of all, they suffer when they experience trauma for the first time. Secondly, they suffer, when mass media take their traumatic experiences out of context and portray them in ways that objectify the refugees. "These trauma stories then become the currency, the symbolic capital, with which they enter exchanges for physical resources and achieve the status of a political refugee" (KLeinman \& KLeInMan 1997, p. 10).

In the same way scholars and anthropologists run the risk of committing the same mistake as the media and the humanitarian apparatus. That is, to decontextualize the 
suffering of the refugees, we must therefore be careful when we read their stories. But at least trying to highlight and look deeper into their narratives can reflect important aspects of human lives - mainly how people confront the challenges of a journey searching for peace, dignity and resettlement. How did they cope during the time of war, and after fleeing to a foreign country?

From this point of view, the main question of this paper is how do immigrant's narratives reflect their experience from different perspectives and their ability to cope? In addition, what can their narratives tell us about gender relations?

This paper starts with two main hypotheses. The first is based on what Lawrence Langer discusses regarding the difficulty of knowledge about the suffering of people living in different regions of the world. He deals with the concept of "confirming knowledge" and how hard it is to believe an atrocity that happened in different parts of the world, because it is beyond imagination. He deals with the importance of language in confirming such tragic events, explaining that: "we need a special kind of portraiture to sketch the anguish of people who have no agency in their fate because their enemy is not a discernible antagonist but a ruthless racial ideology, an uncontrollable virus, or, more recently, a shell from a distant hillside exploding amid unsuspecting victims in a shoptalk or a market square. Before we can present a program for dealing with human misery, we need to represent that misery." (LANGER 1997, p. 53). The second hypothesis is that women were long represented as muted according to Henrietta Moore (BARNARD 2000 , p. 145), which provides us with awareness about the importance of looking into the details of the narratives and how they represent gender relations within the context of the refugee process.

In order to answer these main questions, this paper is based on interviews carried out by researchers with refugees who came to Austria. This paper will present six stories out of fifteen interviews; the stories of three men and three women. Each story has its own uniqueness, whether in the way memories are shared and expressed, or what kind of questions they pose and answers they provide. The interviewees are from Syria and belong to different religions and affiliations, their ages ranging from thirty to fifty.

\section{Remembering the past and the representation issue}

According to Edna LOMSKY-Feder: "The personal memory of war is not homogeneous but, rather, multicolored: Some remember the war as a traumatic experience and others as a heroic event; some recall it as an experience that obstructs personal development, and others as an empowering and fortifying one" (LOMSKYFEDER 2004, p. 82.). 
A lot has been written about this subject, and yet the experiences of each individual and group can be remembered in different ways. Not only from the perspective of a man or woman who experienced a traumatic event, but also the way it is represented by scholars and researchers.

The representation of suffering and the interpretation of images that reflect a painful reality by those who did not experience it have two sides: One side is a powerless local victim and the other someone who is able to take the locals' pain into the global world and has the power to do so. This brings us to the importance of reflecting on how scholars represent the suffering of others and rewrite their narratives in a way that can provide a deeper understanding of their experience.

Undoubtedly, men's experience is different from women who according to Maria Holt experience two types of violence: "the violence that is done to them that is also done to men $\{. .$.$\} . And violence that is enacted upon women because they are women."$ (HoLt 2003, p. 225). The narratives told by women show this aspect clearly when it comes to the fact that they are judged by their society once they were in prison for political reasons. The fact they are women means they have to protect themselves from the insults of men's guards who could harass them while they are in prison.

The fact that everyone, regardless of their gender, deals with their own memories and has a different way of dealing with the past, reveals the importance of narratives for uncovering the different aspects of the human's experience. According to Adelheid PICHLER it also shows how language can be a tool to influence the present, "the present derives its power from a carefully maintained relationship with the past." (PICHLER 2012, p. 139).

Eventually, the sacrifices and agonies people endure during and after a traumatic experience, and the continuously changing behaviour individuals adopt to deal with the past, confirms what Caroline Nordstrom describes: "The present has a meaning because it is embedded in a matrix of past realities and future possibilities" (NORDSTROM 2004, p. 65).

\section{The narrative of three men: The passage of seeking refuge}

The first interview was with Essam ${ }^{1}$, a Christian man who is forty-three years old and has been living in Vienna for almost two years. When he was asked what the toughest part of the process of seeking asylum was, he expressed that it was making the decision to leave his country. The idea itself is a very vital aspect of how the notion of belonging is embedded into the daily life of a person's existence. Considering leaving

\footnotetext{
Essam is not his real name. All the interviewees' names have changed for reasons of ethnographic anonymity and safety.
} 
the country was the biggest challenge, rather than the fear of being a refugee in itself or the life-threatening perils of the journey.

Essam continued to describe the second obstacle he encountered - which was his journey from Syria to Vienna. He left with his wife and children with the help of a friend who introduced him to a smuggler. He had to pay a large amount of money, which is the case for most of the men who were interviewed. Despite the dangers of the journey, his main fear was not the harm that could occur to him and his family. His main concern and fear was to be caught and forced to return back to Syria because he believed that once he returned, his family would be in danger.

His family left Syria and only some of his relatives stayed behind. Not all of the relatives who left Syria are now in Austria, his mother-in-law, for example, is living in France and helped them generously throughout their journey to Austria. He did not explain how his mother-in-law reached France or whether she was there before the situation. His main focus was on his nuclear family.

Recalling his life in Syria, he came from a middle class family and worked for twenty years as a dental prosthetist in his own laboratory. He had a home and a car, both of which he lost during the war. His dream was to help and support his two children through their lives and to provide them with a good future, dreams he expressed were part of being a parent, and his responsibility to guarantee a decent future for his children.

In Austria the same dream remains, but he needs to find a job first, and for that he is continuously trying to contact churches to find for him a job in his speciality. When he was at the refugee camp, he worked for two months in a cave carrying wood and iron.

He hardly communicates with his fellow Syrians, and as a religious man he only keeps in contact with the church. After what he gone through during the war and the threat that he and his family were confronted with, he keeps a distance from others. He believes that ISIS represents the Islamic religion, and keeping in contact with Muslims seems hardly acceptable. As a result, he feels uncomfortable with communicating with different religious groups or any ethnic group in Vienna.

"I am trying to stay away from the other religions but it is compulsory, we live in a mixed city, there are in it from all religions, you can see from all kinds and from all groups but the most thing that scares me is the migration that happened last, that the coming of the radical groups. I try to stay away of them as much as I can. But it is obligatory to contact them."

The way Essam narrated his experience and the answers he provided reflect two main aspects: on the one hand, fear of strangers who do not belong to his family or his small circle. On the other hand, the gender power-relations can be noticed from his narration by excluding his wife from his experience.

His fear of others and current beliefs can be considered as a result of a brutal experience. Experience can shift an individual's beliefs and belonging. At the beginning of the interview he expressed that taking the decision of leaving the country was the 
hardest of all. After all he has gone through - being under threat in his homeland until the end of the refuge journey which is surrounded by fear and risk - may have led him to believe that anyone who belongs to the Islamic religion is a threat. It does not mean what he said is the truth, but this is what he believes. What was missing is to understand the whole context and his relationships with his Muslim friends and neighbours in Syria before the war. He mentioned briefly that he had a good life in Syria until the war. He did not mention any negative experiences or any problem due to his faith during these forty years. It is important to consider that war is an extreme situation which affects a person's way of thinking immensely. As Nicolas ARGENTI and Katharina Schramm put it: "The recreations of the past produced by memory are partial, unstable, often contested, and prone to becoming sites of struggle" (ARGenti \& SChramm 2012, p. 2).

In addition to his fear of strangers, his narrative also clearly revealed gender relations, especially when he described his journey from its start until the end. The decision he took to leave the country and to secure his family was the hardest part of the journey. He did not explain or mention how he took the decision. Did he discuss it with his wife? Did he take it by himself? Was it the decision of "the man of the house"?

Whether he took the decision by himself or after consulting his wife, he did not mention her role. Her role during the decision-making process was not mentioned during his narrative. In addition, he said he wanted to secure his children's future, but where is his wife and what role did she play during the war?

The fact that his wife is missing from his narrative, provides an insight into gender relations in this case. In his story, women are at the margin of the men's narratives despite their important role within the family in the Middle East. This brings us again to Maria Holt who believes that women experience two kinds of violence. But adding to what she mentioned earlier, another dimension can be added which is the underestimation of the role of women during times of crisis. This aspect shows that women not only hold with them the pain of a past experience, but also the inequality they can suffer based on existing narratives. This reminds us of what Paul FARMER says: that not all suffering is equal (FARMER 1997, p. 279).

Essam's narrative shows not only the suffering and the fear he experienced and how he tried to become part of society by finding a job and keeping a distance from others, but also how his wife's role is missing from the memory and narrative of his journey. He did not mention once how she supported him or not through the process of leaving Syria. Many questions remain unanswered that could give a deeper understanding of how he managed and coped during and after his travel to Europe such as: What is his wife's role in Vienna? What is her role in helping the family cope with the new environment?

Moving to another story which provides another perspective about the struggle of moving forward after escaping a war zone: Hassan came to Austria in 2014. He is a thirty-year-old Sunni Muslim who used to work as a driver. When he was asked to describe the stages of his journey in details, he directly said that he stayed about ten 
days in the camp "Traiskirchen" and then around six months in Styria province until he had an appointment and now he has a temporary permit residence which should be renewed annually.

He did not start by describing his fears of leaving his country, or even describing his journey. He started to talk about how he arrived in Vienna only later, when he was asked in the middle of the interview to describe his journey. It was interesting from the beginning that the way he narrated his experience and answered the questions reflected his eagerness to tell what he had experienced and his own opinion about what he had gone through especially in Austria. He was keen to narrate everything in detail which could be considered a way of adaptation despite remembering the past not being an easy thing to do, which brings us to what Srila Roy says: "The need to render memories of violence and atrocity speakable in practices of witnessing and testimony is, at one level, a struggle against the forces of forgetting that keep those memories repressed. At the same time, however, remembering itself can become a mode of forgetting, particularly in the reinscription of traumatic memory into narrative form." (Roy 2010, p. 35).

Describing his life in Syria reflects the satisfaction and happiness he enjoyed then. But when the war broke out, he and his family started to migrate within Syria to be able to survive. As he puts it "we have no choice. This is a reality which imposed on us." By living day-by-day and trying to get by without thinking about tomorrow was the best way to manage life under threat as he explained it. "God creates what he wants so tomorrow will be not the same of today."

He was worried that the regime would force him to fight within its troops, so he left the country leaving behind his pregnant wife. Turkey was his first destination in which he stayed for eighteen days until he went to Greece by sea. Then, with the help of smugglers and walking for a long time he reached Austria. After explaining his journey in detail he said at the end "two months and twenty-one days and ten thousand dollars was the cost for me to be in Vienna." During his journey, technology played an important role, especially to communicate with his family and to assure them that he was safe and to be sure that they were fine. Adding to that, mobile phones with GPS were important to him to ensure he was heading in the right direction when he had to walk to reach his destination.

He wishes he could bring not only his pregnant wife to Austria, but also his siblings and parents. However, his parents made it clear that they would not leave their country under any circumstances; they have lived in Syria their whole life and they would stay until the last day of their lives.

Despite living abroad, he made it clear that he is obliged to support his parents no matter what, especially financially. Even though he did not say if he is able to do it or not, it is clear that if he has the chance to help his parents he will not hesitate.

After he came to Vienna, he started to ask how he could enable his wife to join him. She left Syria and is staying in Turkey at the moment waiting for her husband to help her to come to Vienna. It was obvious that he is the one taking the lead, and his 
wife plays little role in his narration, just that he is trying to help her to get to Vienna. He never mentioned how they both together were able to survive the war, or if both decided to have a child, if they both or only he thought about leaving the country.

In order to deal with being far away from his country and family, he started doing volunteer work when he moved to Vienna, which indicates a certain degree of agency. He did not do nothing while waiting for his visa. He explained how he started to explore how he could be part of the community. He went to the places where the refugees usually come and receive help, and he was able to help by translating. His behaviour and adaption to his situation confirms Murray LASTs' assertion s that healing post war trauma can take place at the community level and be done socially (LAST 2000, p. 328).

Despite trying to be part of a volunteering group, he made it clear that he has no contact with anyone from his community who is from Syria. In addition, he prefers not to communicate with any strangers or people who do not belong to his community. Especially with those who belong to radical groups. Adding to that, religion does not play an important role in his life. He explicitly emphasised that he does not care about what faith people belong to. Muslim, Sunni, Shiite, Christian, or any another belief - he does not care about that.

His answer is not unique, many refugees express that they are not against any different ethnic groups, but they prefer not to interact with strangers, or people who are outside their inner circle. Their answers indicate that they are good persons who are deserving of permanent residency on the one hand. On the other hand, fear of 'the other' can be inferred from their narratives. War not only destroys land and homes, but also trust and faith in others.

At the end, Hassan's main expectation and vision for his future in Austria, was to obtain residency. It was the first thing that came to his mind rather than finding a job. He repeatedly said that, even at the end of the interview his main concern is Austrian residency. He feels that he cannot do anything in Austria unless he achieves this.

The main aspects of Hassan's narration can be highlighted in two main points: First, the role of his manhood; second; the issue of integration and adaptation.

Throughout his narration he showed and expressed his struggle at the Traiskirchen refugee camp. Each detail and each event is linked to how he was able to move forward with his life and try to do volunteer work. He wanted to help his parents, siblings, and his pregnant wife, but he could not because he does not have enough money and no residency according to him. His story reflects that he is a man who took the lead from the beginning and with little help on his way to Europe, and he is very keen to be part of Austrian society. His wife from his narration can be seen as an dependent woman who has no voice, a woman who relies on her husband and is waiting for his help. It reflects the same issue of Essam's narration, which is ignoring the women's role during the whole process of seeking asylum. 
Regarding the second point of integration and adaptation, his way of dealing with the situation reflects contradictory patterns; he is a person with agency who tries to volunteer and be part of the society on the one hand. On the other hand, he is a man who sees that his future relies on obtaining the residency and can hardly move forward in his life without it. His situation reflects that of many refugees: eager to move forward with their lives, but stuck in limbo, waiting for their interviews and to obtain the papers that allow them to do something useful in their host society.

Until now we looked at two stories, and the similarities and differences in their narrations. Now let's move to the third narration which will explain another dimension of how sometimes seeking asylum can be an accident, but is embedded within a whole story of struggle and suffering. This aspect will show us how coping with a difficult situation is very difficult without the support in other variables, especially from official authorities who have a huge importance for the refugee process.

An older Kurdish man who is fifty-eight years-old left Syria and went to Lebanon after he thought he had lost all of his children during the war. Samer's story is a little different form the others since he arrived in Austria with the help of the United Nations.

He introduced himself quickly by name and stating where he is from and ending by saying "we lived in Syria, we had a good life and had cars." It was interesting to mention as a way of introducing himself that he had car once, as if he wanted to demonstrate that Syrians used to have a satisfied life and did not need charity and pity from the world, which is not the case anymore.

Starting by describing his journey to Vienna, he recalls his time before the war. The incident when he thought that he lost his family (seven children and his wife), by a bomb hitting their house, was the turning point of his life that forced him to leave the area where he was living.

The situation was unbearable so he left to Beirut and stayed for two and a half years. Then one day he was captured by Hezbollah, and was forced to return to Syria. A Lebanese man who was charged to drive him back told him to register with the United Nation if he wants to leave the country and this was what happened. He was not planning to go to Europe, and if the Lebanese driver did not help him he would probably have gone back in Syria. He was lucky to have got the help of the United Nations, showing the important role the UN has in throughout the asylum-seeking process. In addition, it may be linked to what FASSIN explains about exercising compassion in public space. "When compassion is exercised in the public space, therefore always directed from above to below, from the more powerful to the weaker, the more fragile, the more vulnerablethreatened and forgotten lives that humanitarian government brings into existence by protecting and revealing them." (FASSIN 2011, p. 4). This indicates the important role that political parties and influential organisations, like the UN, can play in easing the suffering of refugees, if there is the political will to do so. 
He started to talk about Austria and its positive role in helping refugees. Then he said that around a month ago he found out that not all his family members were dead. Two daughters were killed besides his brother, and the other children and his wife were still alive. They fled to Turkey and he is asking the Austrian government to help bring them to Austria. His request of the Austrian authorities shows how agency is difficult without the support of an external factor as already highlighted earlier. By situating the man's narration within the wider context and the structure he is surrounded by, we can obtain an understanding of how refugees create spaces in order to cope and move forward with their lives.

The interview moved forward, and when he was asked what the hardest part of the whole process was, he did not give a clear answer. He emphasised that the hardest part was that he was living in a good condition; he used to have a home, a car, and a job. Then he mentioned that losing his children and knowing they are alive was a turning point and made him very happy and he hopes to reunite with them in Austria so together they can think about the children's future.

The way he answered the questions reflected his pattern of thought. For example, when he was asked who is taking care now of his family and children in Turkey, he answered that he is obliged to support them but he cannot because the money he receives is not enough and he does not work so he is unable to help them. He continued by saying that they rent a flat but they do not have money and he cannot support them. He repeated it several times and did not answer how they managed to live on their own.

His expectation and vision after he moved to Austria and learning that not all his family are dead, is to help his children to have a better of future and continue their studies, to settle and give something back to Austria. He said that Austrian people were so generous to accept him in their country and he believes he should return the favour by being a good citizen. His final words were again to ask the Austrian government or any organisation to help him be reunited with his family.

His experience which is linked to support from the official authorities, made it easier for him to adapt to his new life. Looking forward to the future and planning for his children lives, reflects the acceptance and adaptation process he is going through.

Samer's narration as we notice reflects another dimension, in addition to the role of his wife and the issue of belonging, which is the role of humanitarian organisations and the United Nations during times of conflict. Samer was a lucky man who did not know about the role of the United Nations as many other refugees do not, unfamiliar with the fact that they are allowed to register with the UN and ask for refugee status. Most of the interviews showed that smugglers played the main role in helping people cross borders after taking huge amounts of money. This shows that knowledge is power according to Foucault and obtaining such information whether by chance or by previous knowledge could transform refugee experiences.

In addition, for Samer, it was obvious that his age played a vital role in how he dealt with the situation that he faced. He was moving from place to place without planning 
his next steps, having no energy anymore to give his life some direction. His answers most of the time did not provide a deep explanation of the situation. For example when he was asked how he managed to live during the war with his family before leaving the country, he just said it was a difficult situation, there was not enough food and there were days when they were hungry. And then he mentioned his travel to Beirut then to Vienna which he mentioned several times already. It was as if he was accepting his destiny and waiting for others to help him, which reflects a degree of passivity rather than individual agency.

\section{Analytical overview of the three narratives}

These are the first interviews from three men with different affiliations and backgrounds. Each provides us with a partial answer to the main question on their experience and the adaptation process, or concerning the gender relations.

Regarding the gender relations; the three men made it clear that they are the ones who should support their families and the ones financially responsible. In addition they strongly desire to do so, but they cannot because they do not have a proper income. Their emphasis on this point reflects how important it is for men in Syria to be in charge financially and give their families the money they need, something considered proof of their manhood and their ability to fulfil their role as men.

This point also brings us to the absence of their spouses and the disappearance of the role of their wives throughout the process of adaption during the war and being a refugee in a foreign country. This absence shows a critical issue regarding gender relations in the Middle East; men usually believe they are the ones who have the key role in keeping the family together. However, women in the Middle East play an important role within their families. They are not only housewives, but they also contribute financially to support their spouses. Many prefer to show that their husbands appear in a good position and have the leading role, despite the fact that this may not be the case in reality.

Another interesting point is that it is clear that legal and illegal factors played a vital role during their journey to Europe. The United Nations has an important role in such processes, but so too do smugglers in transporting refugees on a risky journey to Europe.

A common fear that all interviewees share is fear of the other, which is a direct consequence of the traumatic experiences they have gone through. Doubting others' intentions and trying not to communicate with others is a way of adapting to a new society. Of course they show some degree of integration into the new society by trying to do volunteer work and continue looking for jobs to feel they can achieve not only a sense of self-satisfaction, but a sense of belonging in the society. 
That is a partial analysis that can be linked to the main question, but to have a deeper understanding we will move to the women's narratives in order to provide complementary aspects to provide answers for our inquiry.

\section{The narration of three women: individual's agency within the suffering zone}

The next section will focus on narratives told by women who have experienced not only the hardship of war, but also the burden they carry just because they are women. Let's start with a woman in her mid-thirties called Randa.

The way Randa narrated her experience and the answers she provided show a main difference between her and the men regarding their behaviour and ways of coping and dealing with the current situation.

She did not just narrate her experience and share every detail of her past without asking the reason behind it. She questioned the aim of the interview, especially when she expressed that she is sharing very personal details and whether they really needed to be included. She agreed when she was told it is only for research reasons, not for a publication in a newspaper.

The way she narrated her story did not reflect any eagerness to share, the opposite of the interviews with men. There was hardly any repetition from her side on any subject or memory she talked about. She told a story, a memory, and an experience without emphasising specific points repeatedly.

Randa left her family after she reached a point where living in Syria with her family during the war was not an option anymore. Her family who belongs to the Alawite sect (father, mother, and two brothers) and support the Syrian Regime, which she does not. She expressed several times that her family are so supportive and open minded, but the issue regarding the different opinion about what is happening in Syria created a rift between them.

She had a good life before the war. Her family wanted her to complete her studies and work so she could be independent and not reliant on anyone. However, during her studies at the university near her hometown she married without the knowledge of her parents. She quit university to be with her husband, because he did not want her to be at the university. He was a merchant and an uneducated person. He was different from her family's background in which all family members are well educated.

After a year she got divorced and returned to her parents' home. They celebrated her divorce and held a party for her that she was free from the man who mistreated her. For around four years she stayed at home without work and then she decided to continue with her studies in Damascus studying literature and fine arts. This aspect shows us 
that she is a determined person, who is ready to move forward with her life and not pity herself for her past decisions. It could be that the support of her family has a major influence in developing in her a strong personality, taking responsibility, accepting the facts and learning lessons from her past. In addition, she worked at the airport in the dutyfree section for three years until she had to resign after the problems and accusations she faced during the war. The person who was in charge had a high position in the regime, and she used to write vague sentences from time to time on her Facebook page about the situation in Syria, but without explicitly expressing her opinion. At the end, she had to quit and return home to stay with her parents. Again, her resignation and non-acceptance of the political situation was countered with small actions to show her rejection to the regime through the social media. Despite the fact that she knew that her actions could lead to unpleasant results, she continued with what she believed in. Her actions show Randa to be a rebellious person who does not follow orders without questioning it. This aspect will affect her journey to Europe and her way of coping.

She expressed that the revolution at the beginning was a true revolution, but now it was mixed and not the same as when it started. After few months, her father told her that he just wanted to see his daughter smile. He gave her money so she could get out. She did not explain exactly how her family supported her to leave Syria, but it seems that her parents accepted the idea of letting her leave the country, especially as she made it clear that she could not live in Syria anymore and be surrounded by people supporting the regime. At some point she feared for her life and felt threatened by others, but not her family.

According to Randa, her journey to Vienna was not hard, it took her six days to reach her destination. She flew to Turkey and then she paid for a driver who took her and others to Vienna for a large amount of money and everything went fine. It seems her financial situation is good and her family did what they could to let their daughter reach safety.

When she reached Austria she went to Traiskirchen. She was supposed to stay with seven other people in a very small room and the toilet was not very clean. So she used Google Maps and searched for a nearby hotel where she stayed for a few days. She was lucky because after the fifth day she had her second interview and she received her asylum papers. After receiving her papers and leaving Traiskirchen her friend helped her to find a place to live, which is with other girls. She is not completely comfortable at the new place, but she cannot afford other places because she does not have enough money.

Since she came to Vienna a feeling that she does not know where she belongs was a main issue in her life. She feels that she has no roots anymore, despite the fact that she communicates with her family frequently using Skype and Viber. They talk about everything but politics.

Even in Vienna, she makes it clear that participating in demonstrations against the regime in Vienna is useless; whoever wants to do something for Syria should go there 
to help. For her she will not be part of any group or participate in such events. What she witnessed in her homeland is enough for her.

After staying for more than a year in Vienna, she stated that she has many thoughts about what she should do with her life. She wants to return to her home, but she cannot because she feels it is not hers anymore. She wants to go to Jordan, Lebanon or any place where there are camps for refugees so she can help them. Then she said, she is selfish, she wants to start a new life, not think about anything in Syria. She hopes to continue her studies and obtain a PhD degree. At the end she said she does not know what kind of feelings she has, she is stuck and not settled anywhere yet. Once she had a home, a family who would do anything if she was in trouble, and now she feels insecure having only one friend but not a family.

\section{Main analytical aspects in Randa's narration}

Randa's struggle and suffering is more about belonging. Randa obviously has a family with a good income, home, and their situation is much better than others in Syria. But she could not stand the idea that people from other parts of Syria are killed because of their beliefs and affiliations. She preferred to leave everything behind and be alone, rather than live in a place where she is witness to the killing of her own people. Her struggle explains what Allen Feldman says: "There is no doubt that memories of the past say a great deal about people's attitudes in and towards the present." (FELDMAN 2006, p. 15). In Randa's case, her memories seem not only to shape her present, but her future as well.

It is interesting how Randa's narrative differs from the male narratives. An awareness of integrating stories about herself and her own struggle with those about the revolution and the political situation and explaining in detail how it was a true revolution in the beginning but not anymore. She was not the main focus of her narration the whole time, but included the role of her family, friends, and even tried to describe the whole political situation, including herself within the narration.

Furthermore, Randa showed agency rather than passivity towards her life. She did not just accept the situation and follow the stream, rather she was a kind of rebel despite the fact that she could live in a good condition if she just agreed with her family politically. Of course Randa could be considered a privileged refugee, but what about other women from different affiliations?

\section{Sohad: between suffering and coping}

A woman who is thirty-seven years-old, two years older than Randa, and belongs to a different ethnic group - the Yezidi - has a different story and different way of narrating her experience. 
Sohad introduced herself as a married woman with five daughters. She gave very brief answers and needed to be asked to share her thoughts, again it seemed she feared being open. This especially came to light at the end of the interview. She said that even now in Austria, she is afraid of telling others that she is Yezidi. In addition, she is not keen at all to meet new people and contact others who with her on her journey to Austria. Her brief answers could be understood by David MorRIs' words that: "the silence of suffering also points to very practical breakdown of speech $\{. .$.$\} the voicelessness of$ suffering often resembles the quiet retreat of people who live with chronic pain" (MORRIS 1997, p. 28).

Before the war she and her husband were settled and had their own home. Both had a job. Life was comfortable, her girls went to school, and everything according to her was normal. Her dreams were simple - she wanted to keep her comfortable and happy life and to see her daughters grow up and receive the best educational opportunities.

After the war everything changed and their dreams became lost under the threat and destruction. Their daily struggle was to obtain the minimum requirement they needed. Even the food was hard to have, and bread became expensive. Even when she tried to bake by herself, she stumbled several times due to not having a fire.

The situation became worse when her husband went to a demonstration and was beaten badly on his head. Since then he suffered from epilepsy and had couldn't go back to his job at a construction company. She became the breadwinner of the house, carrying the burden on her own. Especially as all of her extended family had enough problems to deal with.

Despite the lack of food and the bombing, they stayed in their home, until one day ISIS fighters came to their home to ask for water. Sohad and the girls were terrified, especially because they knew that ISIS usually takes Yezidi women and sells them. She called her brother-in-law who came directly and arranged a car for her and all of them to leave Aleppo to Afrin.

That was the moment when they all took the decision to leave. The fear of ISIS and the threat the Yezidis are exposed to because of their beliefs terrified them. A month after leaving with her family, her home was bombed and destroyed. She thanked God for not being there when it was destroyed.

She did not explain how she knew her house had been destroyed or whom she asked to obtain such information. But knowing the exact date of the destruction of her home, shows that she never forgot or lost hope of returning to her house. She kept asking about the place where she lived until that day.

After staying four months in Afrin, she and her family went to Turkey where they stayed for two years. She was not able to register her daughters to school, and she did not receive any help as her daughters did not know the language.

She became pregnant and wanted an abortion because she could not carry on taking care of five kids and her husband who was sick and could not work. The hospital 
in Turkey rejected the request as it is not allowed. After they heard her story and how she is the one who takes care of her family they suggested that she apply for asylum through the United Nations and to help her to transfer her papers to them if she accepts. She agreed and was happy to hear that there would be the possibility to obtain asylum somewhere in Europe. She agreed even before asking her husband or anyone. But she asked them if she could include her sister and her family. After a week she received an answer of acceptance. Her sister was sent to Luxemburg, and she went to Vienna.

The hardest part of her asylum process according to her was that she was not able to say farewell to her mother. She did not explain the reason behind that. But leaving her mother behind was the hardest decision. Her mother is not alone; she has a father and other siblings. Some family members were already smuggled to Belgium and she has a sister in Germany. She did not explain in details how many siblings she has, but it seems they are a close family despite the distances and they keep in contact by phone.

She had not expected the warm welcome when she reached Vienna. It was a great moment for her to see people taking care of her and her family. Now that she is settled in Vienna, she still has the same dreams she had once while she was in Syria. To have a decent life and to see her children receive a proper education. They are already at school now, and she compared and contrasted their situation in Turkey with their situation in Austria. How they were not allowed to enter school because of the language issue, and in Vienna despite the fact that they still do not know the language, they were registered and now have the opportunity to move forward with their lives.

Adding to her old dreams in Syria, new dreams arise. She wants to start a new profession. She used to work in sewing, but now has hopes for a new profession in Austria. She wants to study cosmetology, and she already started to ask about the possibility of doing this. It seems she started to find a daily routine and peace in Vienna. However, if she had the chance to return one day to her hometown, she would, but emphasised that she would not force her daughters to return if the war ended. It is their choice to choose the path they want for their future.

At the end of the interview she was thankful for the talk and conversation. It was a relief for Sohad to express her feelings and to share difficult experiences.

Sohad's narration not only reflects her desire for a simple life, but also that she is a person who does not hold a grudge against others or show hatred. Despite the fact that Yezidi women suffered a lot, but she did not keep emphasising issues of hatred and about others, as the men had. She focused on the future and looked through a new lens, seeing a new path for her and her family.

In addition, she was the one who held the family together, kept working under fear, and kept her true religion hidden so she would not be taken by ISIS. She worked day and night but did not complain once during the interview. She is a practical, proactive woman, who deals with what she has in a way that can help her family. 


\section{Ruba under social and political obligations}

Now let's move to the last story which is about a thirty-five year old Sunni Muslim woman called Ruba who was divorced after being released from the Syrian regime's prison where she had been imprisoned for seven months. Her story not only reflects the suffering of the Syrians, but also gives another perspective of the experience of women during the war.

She is a maths teacher and activist. Since the revolution she started to be part of different groups who worked via social media. She did not hesitate to express her beliefs and stand against the Syrian regime. In March 2012 she was arrested. "They put me in jail underground for seven months. Of course they beat me there," she said. What is worth considering according to her is that women who are fighting with the revolution are confronted not only by the oppression of the regime, but also the social norms which considered women who are arrested to bring shame on families: "the woman, when they arrested her and she is out, she is a victim again because the family and the society they feel that she is something shameful because she has been a prisoner, because they rape many women. And now if the woman raped or not, in the mind of people maybe they raped her. Okay, even if she was raped, she is a victim, it's not her choice. That's why I'm telling you that she paid double price."

She was among those women who got divorced as a result of their imprisonment. Ruba did not act like a victim. She kept working against the regime despite the revolution not being the same anymore as when it started. Many groups are now fighting in Syria and it is not pure as when it started.

She started to think about leaving the country. Luckily, she received an invitation for a conference from the Democrat party, a political party in Turkey. She could not stay longer in Syria after the situation worsened, especially when her brother who was arrested by the Syrian regime in 2012 was killed in 2014. She could not wait until this happened to her, so she left for Turkey.

In Turkey she worked for the interim government for a few months, until she found it impossible to continue as she explained "I resigned, I had problems with them. Because for months we work for free and there also I have to pay rent. It's a studio, but still, and at that time I brought my mum from Syria, when my brother died, my daughter followed me with her son, my other daughter from Jordan, because there the horrible life also there, they came to me. So I can't anymore."

At this moment, her journey to Europe began. It was not easy - as it is not for any refugee who leaves their country. It was even harder for her, because she was not only responsible for her life, but also for the lives of her daughters who were pregnant and her elderly mother who could barely walk. The road was full of danger, and the rubber boat almost sank several times. They had to walk for long distances and had no proper shower - feeling cold and humiliated. 
Her journey was not easy compared to other Syrians who were interviewed. She did not go directly to Austria. She wanted first to be sure that her mother would have a good place. She tried many ways over land and even a fake passport to go through the airport. "There from the airport to Paris and then I took taxi from the airport to the train station to Belgium, then to Holland, Netherland, I put my mum there, because my sister is there and her daughter is there and I have a cousin there. I left them there and then I took the train and I came back to Germany. First city I change the train and in Munich I stayed one night and I continued to Austria."

She chose Austria for two reasons; because her daughter has been living in Vienna for six years before the Syrian revolution started. The other reason is that she knows Vienna due to her previous visits when she was married. Her husband used to be a manager of Syrian airlines, and she used to travel very often.

She settled with her daughter initially who supported her financially until she received money from the social system. Now she is settled in Vienna, and her age was not an obstacle to keep working on what she started in Syria. She has been working with the Syrian opposition from Vienna. She joins them each Sunday for a demonstration near Stephansplatz to remind the people about the Syrian revolution. Adding to that, they prepare food and sell it to send the money to families who are in need in Syria, especially women who are housewives.

Not only does she work with the opposition, but she also volunteers at refugee camps inside Vienna and even goes to the Hungarian border to help the doctors with translation. Ruba has shown a remarkable way of integrating into the society despite her old age. This is the opposite of Samer whose age reflects a main obstacle of taking any action by himself. She did not act like a victim, and took a decision to move forward with her life.

\section{Analytical aspects of Ruba's narration}

The last narrative shows us another dimension of the women's struggle besides the consequences of the war, which is how society looks at women if they participated in political issues and went to prison. Being in prison for political reasons means that women face the brutality of immobility, but are also subjected to men in power and physical and sexual abuse, which is not accepted by society and counters the concept of the honour of a woman's body.

Despite that, her way of coping with the situation was and still is to be involved in political activities as a way of moving forward with her life. She got divorced because of her political involvement, and even then she did not stop following her own will. Even after she arrived to Vienna, her political activities were a major way for her to adapt to what she had gone through.

The way Ruba expressed her opinion and thoughts throughout the narration is the opposite of how the three men narrated their stories, but it does not mean that this is 
generally the case for all the refugees who seek asylum. For example, she did not hesitate to criticise the fact that Austria still keeps the Syrian embassy in Vienna. She was not afraid to speak her mind loudly no matter the sequences. On the contrary, the men did not criticise any aspect, and emphasised that they are looking forward to obtaining the residence permit. Ruba did not mention her status in Vienna and what type of visa she has.

Her story is also similar to Randa's how she described the revolution and situated their stories within the events that happened during the war and throughout the asylum seeking process. At the end, Ruba believes Syria will one day have peace as it did once, with people living side-by-side regardless of their affiliation or religion. Now she has new dreams in Vienna, she is settled and has hopes for a better future. She wants to learn the language, help other refugees, and work so she can be part of the society.

\section{Summary}

It is hard to generalise the analysis we have, but it can give us an understanding of important aspects that the paper aims to address, especially regarding gender and the ways of coping and adapting after experiencing being a refugee and living in a foreign country.

The narratives told by refugees from Syria, reflect how they have shown a great deal of agency regardless of gender. Men and women both tried to find their way towards a future that can give them hope and peace. It was striking that the fear of others and losing faith in people was a common theme in most stories, and they preferred to be far from strangers and people who belong to another belief or religion. Furthermore, the theme of belonging was also prominent in the refugees' narrations regardless of gender. This showed that the attachment to a specific place does not necessarily change when the refugee obtains the asylum papers and is granted the opportunity for a new life.

In all of the male narratives, the role of women and their families during the war, the journey and the asylum seeking process was marginalised. Women were totally absent and considered a shadow to their men rather than partners who look together towards a better future for their families. The contrary was the case for the stories told by the women who were interviewed. Their stories included the role of their husbands, fathers, and friends, rather than concentrating on their role alone - despite the fact that they showed strong agency. Language used by men and women in their narratives often reflects different expectations in their society. In Arab societies, men are supposed to present themselves as breadwinners and main supporters of their families. This puts women at the margins in their narratives. On the contrary, language used by women during their narratives indicates the existing solidarity among family members, for example, through the frequent use of the personal pronoun "we". 
Of course, coping in a foreign country is not easy, and every person has his/her own way of coping and adapting to a new environment. Voluntary work was an important start for most to override the idea that they are refugees and prove to themselves that they can integrate and be part of the society.

Nonetheless, searching for a job or continuing their education was a vital issue. Being independent financially or having an aim in their lives could be a way of giving refugees self-confidence a sense of productivity, not only humans who cannot afford full participation in society. However what was striking was that mostly, the women that were interviewed seem more practical than men regarding the adaptation process. For example, when a man was asked where he prefers to live, he emphasised that he cannot live in a village and he came from a city and has to stay living in a city. On the contrary when a woman was asked where she prefers to live, she explained that a place where she can start over her life, support her family, and has a job would be fine for her. Of course, we cannot say this attitude applies to all refugees, but it was interesting that among the interviewees these aspects exist. Even if further analysis in the future shows us this aspect applies for both men and women, then individuals regardless of their gender, stay focused on their personal desires rather than being practical and focusing on what they have. These aspects indeed can be elaborated on in further analysis and future research, but for now this example helps to reflect on different ways that women handle their refugee status, and how it can be considered an important indicator of their ability to shape the futures of their families in a positive way.

In conclusion, the different mechanisms of coping during the war and the process of fleeing the country reflect the larger social and political forces that took place behind the scenes. Despite the narratives focusing more on personal details, and how each person found their way to get abroad, it is clear that the relations each person has with their family, political party, affiliation and belonging had a strong influence on how each person's journey took shape. For example, it seems women were less worried about obtaining their asylum visa than men, because generally they obtained it more easily. Moreover, for some the journey was easier than for others, for example when we compare the stories of Randa and Sohad. A refugee with a better financial situation will most likely have an easier journey to Europe than refugees with less financial means. Many factors played a vital role, not only in shaping the past experience for each refugee, but in what kind of future awaits them. 


\section{Bibliography}

Argenti N, \& Schramm K. (eds.) (2012), Remembering Violence Anthropological Perspectives on Intergenerational Transmission. New York, Berghahn Books.

Barnard A. (2000), History and Theory in Anthropology. Cambridge, Cambridge University Press.

FARMER P. (1997), On suffering and structural violence: A view from below. In: KleINMAn A., Veena DAs, V. \& Lock M. (eds.): Social Suffering, Berkeley, University of California Press, pp. 261-283.

FAssin D. (2011), Humanitarian Reason: A Moral History of the Present Times. Berkeley, University of California Press.

Feldman A. (2006), Home as a Refrain: Remembering and Living Displacement in Gaza. In: History and Memory, Special Issue: Home and Beyond, Vol. 18, No. 2, pp. 10-47.

Holt M. (2003), Palestinian Women, Violence, and the Peace Process. In: Development in Practice, Vol. 13, No. 2/3, pp. 223-238.

Kleinman A. \& Joan K. (1997), The Appeal of Experience; The Dismay of Images: Cultural Appropriations of Suffering in Our Times. In: Kleinman A., Das V. \& Lock M. (eds.), Social Suffering, Berkeley, University of California Press, pp. 88-126.

LAnger L. (1997), The Alarmed Vision: Social Suffering and Holocaust Atrocity. In: KLeinman, A., DAS V. and Lock M. (eds.), Social Suffering, Berkeley, University of California Press, pp. 47-67.

Last M. (2000), Reconciliation and Memory in Postwar Nigeria. In: Das V. Kleinman A., Ramphele M. and Reynolds, P. (eds.): Violence and Subjectivity. Berkeley, University of California Press, pp. 315-332.

LOMSKy-Feder E. (2004), Life Stories, War, and Veterans: On the Social Distribution of Memories. In: Ethos, Vol. 32, No. 1, pp. 82-109.

Morris D. (1997), About Suffering: Voice, Genre, and Moral Community. In: Kleinman, A., DaS V. and Lock M. (eds.): Social Suffering, Berkeley, University of California Press, pp. 2545 .

Nordstrom C. (2004), Shadows of War: Violence, Power, and International Profiteering in the Twenty-First Century. Berkeley, University of California Press.

Pichler A. (2012), Memories of Slavery: Narrating History in Ritual. In: Argenti, N. and Schramm K. (eds.), Remembering Violence Anthropological Perspectives on Intergenerational Transmission. New York, Berghahn Books, pp. 135-164.

Roy S. (2010), Wounds and 'Cures' in South Asian Gender and Memory Politics. In: BradBy, H. and Hundt G. (eds.), Global Perspectives on War, Gender and Health. The Sociology and Anthropology of Suffering. Surrey, Ashgate, pp. 31-50. 
